\title{
Pemetaan Status Unsur Hara Fosfor Perkebunan Kelapa Sawit Rakyat di Kelurahan Babat Sumatera Selatan
}

\author{
Oil Palm Plantation's Phosporous Mineral Mapping on Babat District South Sumatera \\ Bagus Iswahyudi ${ }^{1 *}$, Bakri Bakri ${ }^{2}$ \\ ${ }^{1}$ Program Studi Magister Ilmu Tanaman, Fakultas Pertanian, Universitas Sriwijaya, \\ Palembang 30139 \\ ${ }^{2}$ Jurusan Tanah, Fakultas Pertanian, Universitas Sriwijaya, Indralaya 30662 \\ ${ }^{*}$ Penulis untuk korespondensi: bagus.iswahyudi.bagus@ gmail.com
}

\begin{abstract}
Soil nutrient status mapping was not initiated which lead to inefficiency in fertilization. Fertilizition without nutrient analysis could lead to nutrient deficiency or toxicity of nutrint. The Purpose of this research was to identify, map the nutrient status and fertilization recomendation of phosporous nutrient status in public oil palm plantation at Babat Village Babat Toman Districts Musi Banyuasin District South Sumatera Province. This research used a detailed survey methode with grid system for 16 sample which represent 16 ha and $60 \mathrm{~cm}$ depth of soil drilling. Phosporous nutrient status at research location ranged from $4,81 \mathrm{ppm}$ to $21,86 \mathrm{ppm}$. 7 ha contained $8-20 \mathrm{ppm}$ available phosphorous ot classified into medium, 6 ha contained $<8 \mathrm{ppm}$ available phosphorous or classified into low and $3 \mathrm{~h}$ contained $>20 \mathrm{ppm}$ available phosporous or classified into high. Soil reaction $(\mathrm{pH})$ of the research field was 5,0 and 5,5 which classify the soil into acid soil. Fertilization implemented to increase the nutrient status until medium (15 ppm) which resulted in SP-36 doses was 346,22 kg/ha for low nutrient status and 139,33 kg/ha for medium nutrient status.
\end{abstract}

Keywords: fertilizer doses, oil palm, phosphorous, soil nutrient mapping

\begin{abstract}
ABSTRAK
Pemetaan unsur hara di lokasi penelitian belum pernah dilaksanakan sehingga pemupukan menjadi tidak efisien. Pemupukan tanpa didahului analisa unsur hara dapat beresiko terjadinya defiesiensi atau toksisitas unsur hara. Penelitian ini bertujuan untuk mengetahui dan memetakan status unsur hara serta memberikan dosis pemupukan fosfor di lahan perkebunan kelapa sawit rakyat di Kecamatan Babat Toman Kecamatan Babat Toman Kabupaten Musi Banyuasin Provinsi Sumatera Selatan. Metode yang digunakan dalam penelitian ini adalah metode survei detail dengan menggunakan sitem grid sebanyak 16 titik sampel mewakili 16 ha lahan dengan kedalaman pengeboran $60 \mathrm{~cm}$. Status unsur hara P pada lokasi penelitian berkisar dari 4,81 ppm sampai 21,86 ppm. 7 ha lahan memiliki P-tersedia 8-20 ppm atau golongan sedang. 6 ha memiliki P-tersedia $<8 \mathrm{ppm}$ atau tergolong rendah. 3 hektar memiliki P-tersedia $>20 \mathrm{ppm}$ atau tergolong tinggi. Nilai $\mathrm{pH}$ pada lokasi penelitian berkisar antara 5,0 dan 5,5 sehingga tergolong dalam tanah masam. Pemupukan dilakukan untuk menaikkan status unsur hara menjadi sedang (15 ppm) sehingga rata-rata dosis pupuk SP-36 adalah sebanyak $346,22 \mathrm{~kg} / \mathrm{ha}$ untuk status unsur hara rendah dan $139,33 \mathrm{~kg} / \mathrm{ha}$ untuk status unsur hara sedang.
\end{abstract}

Kata kunci: dosis pupuk, fosfor, kelapa sawit,pemetaan unsur hara 


\section{PENDAHULUAN}

Kelapa Sawit (Elaeis Guineensis
kacq)adalah komoditas negara dan perkebunan rakyat.

Produksi perkebunan kelapa sawit rakyat lebih rendah dibandingkan dibandingkan perkebunan swasta dan negara. Perbandingan luas antara perkebunan kelapa sawit rakyat, swasta dan negara adalah 45,64\%, 49,17\% dan 5,19\% namun terdapat perbedaan yang besar antara produksi perkebunan rakyat $(11,58$ juta ton atau 2,06 ton/ha), swasta $(57,24$ juta ton atau 3,13 ton/ha) dan negara $(1,89$ juta ton atau 2,66 ton/ha). Hal ini disebabkan oleh budidaty yang kurang tepat di perkebunan kelapa sawit rakyat salah satunya pemupukan.

Seluruh tanaman membutuhkan tanah yang subur agar dapat menghasilkan hasil yang berkualitas tinggi termasuk kelapa sawit. Tingkat kesuburan tanah dipengaruhi oleh beberapa hal, salah satunya kandungan unsur hara. Salah satunya adalah unsur hara fosfor. Unsur hara fosfor merupakan unsur hara esensial kedua setelah unsur hara $\mathrm{N}$ dimana unsur hara fosfor berperan dalam memacu pertumbuhan akar, pembentukan biji dan buah,aktivator enzim serta memacu pertumbuhan generatif tanaman (Hanafiah., 2014). Defisiensi unsur fosfat dapat menyebabkan pengurangan divisi sel, metabolisme karbohidrat, kadar protein terlarut dan akumulasi bahan kering (Lambers and Plaxton, 2015).
Fosfor sebagai unsur hara makro tidak banyak tersedia di tanah walaupun dibutuhkan tanaman dalam jumlah yang banyak. Ketersediaan fosfor dalam tanah adalah 100 kali lebih sedikit dibandingkan total P (Hinsinger et al., 2011). Hal ini disebabkan oleh sebagian besar bentuk $\mathrm{P}$ terikat oleh koloid tanah sehingga tidak tersedia bagi tanaman (Umaternate, 2014). Ketersedian ion $\mathrm{P}$ pada tanah yang subur biasanya hanya sekitar 0,1 dan $10 \mu \mathrm{M}$ (Frossard et al., 2000). Nilai ini lebih sedikit dibandingkan dengan kebutuhan ion $P$ yang dibutuhkan untuk pertumbuhan tanaman (Föhse D and Jungk, 2015). Sehingga petani harus rutin memberikan fosfor pada tanah. Unsur hara P diberikan dalam bentuk pupuk fosfat TSP, Phonska, Sp-36 dan rock phosphate.

Pemberian pupuk $\mathrm{P}$ berlebihan dapat menaikkan P-tersedia namun juga dapat menurunkan kualitas tanah. Pemberian $30 \mathrm{~g}$ TSP akan meningkatkan P-total 6855 $\mathrm{mg} / \mathrm{kg}, \quad \mathrm{P}$ tersedia $414 \mathrm{mg} / \mathrm{kg}$ namun terjadi penurunan $\mathrm{Ph}$ sebesar 0,2 dibandingkan tanpa pemberian pupuk (Faizin, 2015). Penurunan $\mathrm{pH}$ tanah dikarenkan pemberian pupuk fosfor yang menaikkan kelarutan ion $\mathrm{Al}$ dan Fe tanah (Rosmarkam, 2002). Secara umum, pemberian pupuk makro secara berlebihan dapat mengakibatkan eutrofikasi karena hara yang terbawa oleh air, mempengaruhi aktivitas mikroorganisme fiksasi $\mathrm{N}$ dan emisi $\mathrm{N}$ oleh pemupukan N. Penelitian mengenai status unsur hara fosfor di lokasi penelitian belum pernah dilaksanakan. Penetuan status unsur hara dapat membantu perbaikan pengelolaan kebun. Untuk itu, penelitian ini bertujuan untuk menentukan status unsur hara fosfor, nilai $\mathrm{pH}$, rekomendasi pemupukan di perkebunan kelapa sawit rakyat di Babat dan disajikan dalam bentuk peta status unsur hara.

\section{BAHAN DAN METODE}

Penelitian ini menggunakan metode survei detail dengan observasi langsung ke lapangan. Luas areal studi sebesar 16 hektar 
berdasarkan pengamatan dan pengukuran. Pelaksanaan penelitian ini terdiri dari tiga tahapan, yaitu survei pendahuluan, survei utama dan analisis laboratorium.

\section{Survei pendahuluan}

Survei pendahuluan bertujuan untuk mengetahui gambaran umum lokasi penelitian, meliputi tinjauan kondisi lahan lokasi penelitian pembuatan peta dasar dan penentuan titik pengamatan dan titik sampel tanah dengan metode grid. Tinjauan kondisi lahan lokasi penelitian dilakukan menggunakan buku dan pulpen untuk mencatat kondisi lapangan meliputi foto lokasi menggunakan kamera (Gambar 1 dan 2) dan penetapan batas wilayah lahan menggunakan GPS Garmin untuk menentukan luas lahan dan data track peta dasar. Foto lokasi penelitian disajikan pada, Pembuatan peta dasar dilakukan menggunakan aplikasi ArcGIS 10 menggunakan data track GPS sehingga dihasilkan data batas wilayah lokasi penelitian. Penentuan titik pengamatan dan pengambilan sampel tanah dilakukan menggunakan aplikasi ArcGIS 10 dengan bantuan grid berukuran $100 \times 100 \mathrm{~m}$ sehingga didapat hasil akhir berupa peta dasar lahan penelitian (Gambar 3).

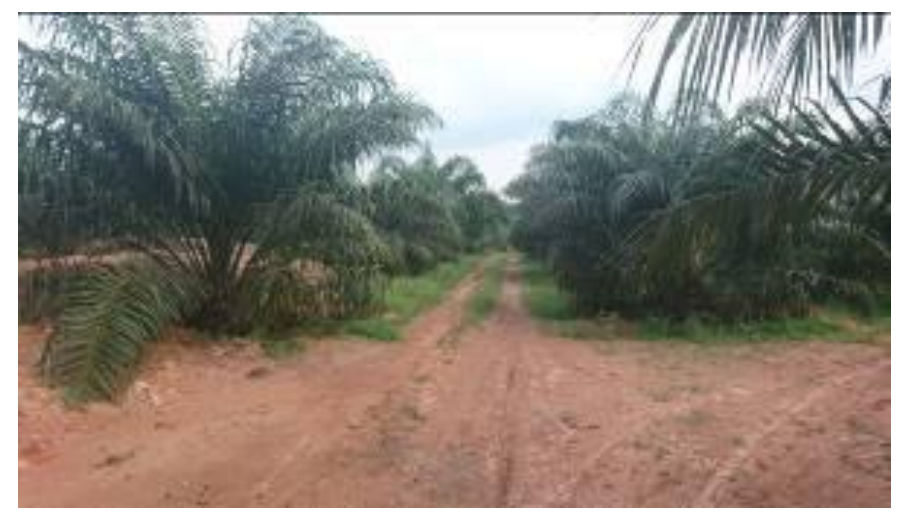

Gambar 1. Jalan utama perkebunan kelapa sawit lokasi penelitian

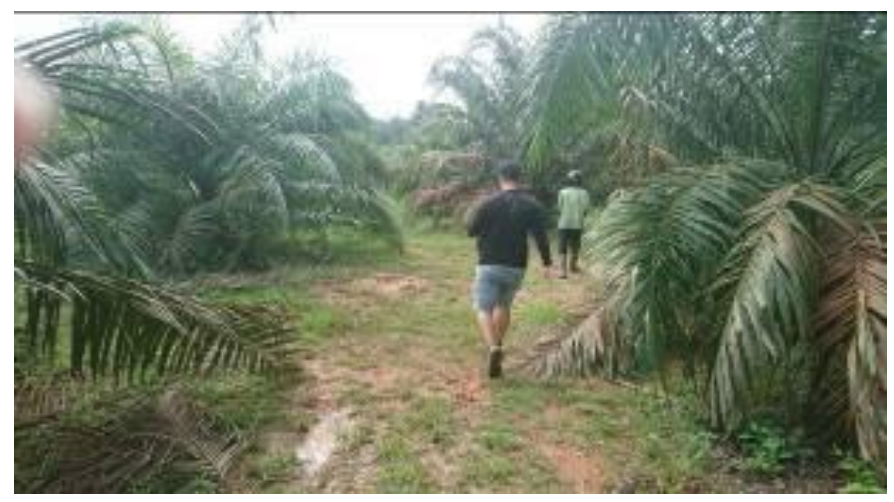

Gambar 2. Jalan antara baris kelapa sawit lokasi penelitian 


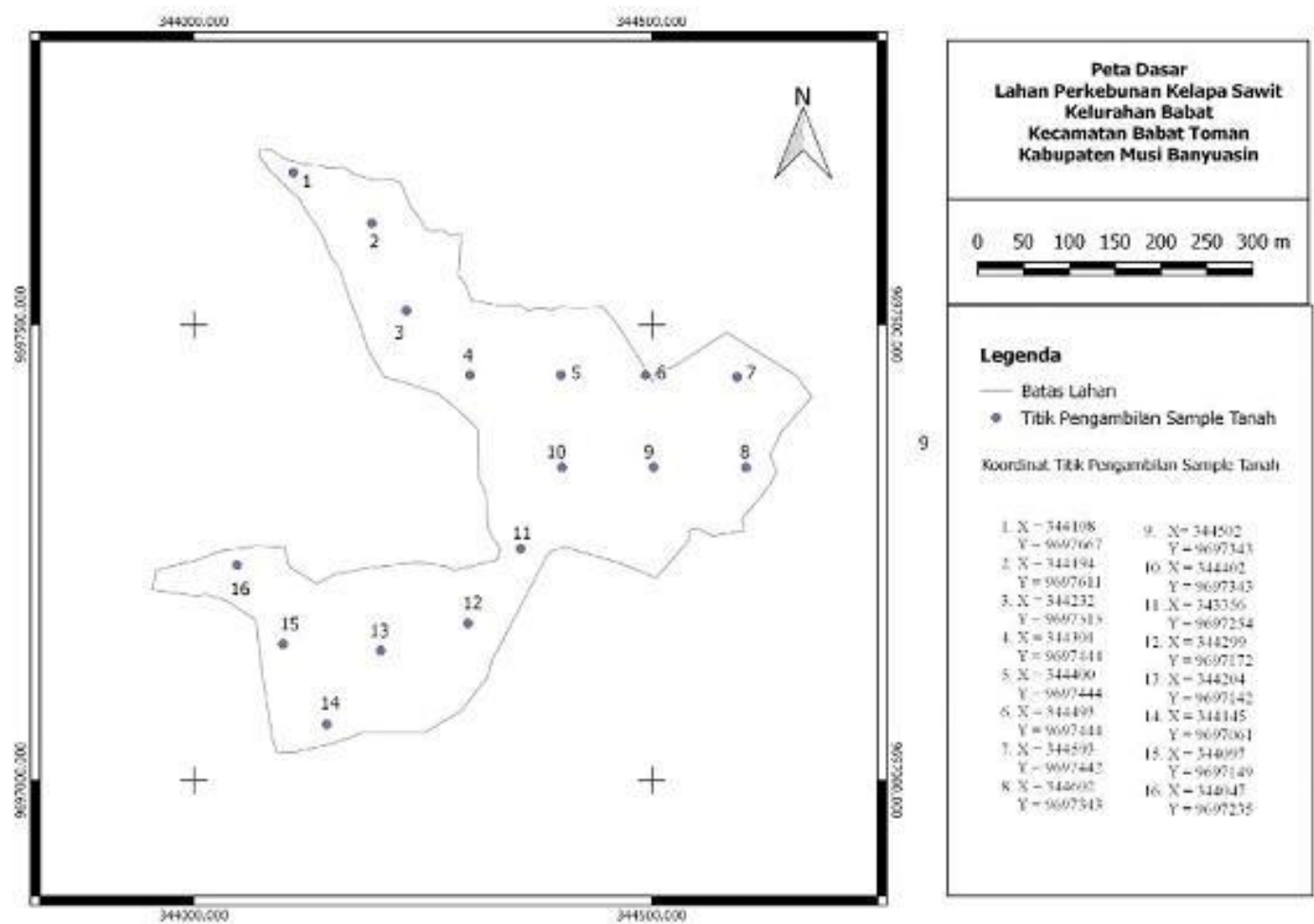

Gambar 3. Peta dasar lahan kelapa sawit rakyat

\section{Survei utama}

Survei utama bertujuan untuk melakukan pengamatan lokasi, pengambilan sampel tanah dan penetuan data $\mathrm{pH}$ tanah pada setiap titik pegamatan. Sampel tanah diambil dengan menggunakan alas, bor belghi, botol kecil, karet gelang, meter ukur, plastik, skrap, spidol. Sampel tanah didapat dengan melakukan bor di tanah dengan bor belghi dari permukaan sampai kedalaman $60 \mathrm{~cm}$ dengan panduan meter ukur dan karet yang diikat di sekitar batang bor belghi. Pengambilan sampel dilakukan tanpa membasahi tanah. Tanah kemudian ditebar di atas alas yang sudah ditulis garis dari 0-60 cm. Kemudian, dokumentasi dilakukan dengan memotret sampel tanah disamping dengan garis ukuran panjang tanah dari 0 sampai $60 \mathrm{~cm}$. Sampel tanah kemudian diaduk dari lapisan atas sampai bawah agar homogen. Selanjutnya semua sampel tanah di atas alas dimasukkan kedalam plastik yang sudah diberi kode sampel dan diikat. Penentuan $\mathrm{pH}$ tanah dilakukan setelah tanah dihomogen. Langkah penentuan adalah dengan memasukkan contoh tanah yang telah homogen secukupnya kedalam botol kecil berisi air dan dikocok selama \pm 10 menit. Indikator $\mathrm{pH}$ kemudian disentuhkan ke permukaan air di dalam botol sampai $\mathrm{pH}$ tanah telah ditentukan berdasarkan warna kertas indikator $\mathrm{pH}$. Prosedur dilakukan pada setiap titik pengamatan sampel. Sampel tanah kemudian disimpan untuk dibawa ke laboratorium untuk mendapatkan data P-tersedia tanah.

\section{Analisis laboratorium}

Analisis laboratorium dilakukan untuk mendapatkan data p-tersedia sampel tanah. Analisis dilakukan di Laboratorium Sampoerna Agro Palembang dan Laboratorium Kimia Biologi dan Kesuburan Tanah Jurusan Ilmu Tanah Fakultas Pertanian Universitas Sriwijaya. Analisa menggunakan metode P-bray II dalam satuan ppm dan $\mathrm{mg} / \mathrm{kg}$.

\section{Peta dan dosis pemupukan}

Peta dibuat menggunakan data hasil analisa P-tersedia di laboratorium. Peta dibuat dengan menggunakan fungsi IDW ArcGIS 10 dan matching kriteria P-tersedia kelapa sawit CSR/FAO (1983). Dosis pemupukan dibuat untuk menaikkan unsur 
hara menjadi sedang dengan jumlah 15 ppm per sampel sesuai CSR/FAO (1983).

\section{HASIL DAN PEMBAHASAN}

\section{Unsur hara Fosfor $\left(\mathbf{P}_{\mathbf{2}} \mathrm{O}_{\mathbf{5}}\right)$}

Berdasarkan hasil analisa tanah dan kriteria $\mathrm{pH}$ di laboratorium, diketahui bahwa lahan penelitian memiliki $\mathrm{P}$ tersedia yang bervariasi. Konsentrasi $\mathrm{P}$ tersedia bervariasi dari yang terendah 4,81 ppm sampai yang tertinggi $21.36 \mathrm{ppm}$. Satu titik sampel mewakili satu hektare luasan lokasi penelitian. Tabel 2. menunjukkan bahwa 16 hektar di lahan perkebunan didominasi dengan $\mathrm{P}$ tersedia yang tergolong sedang.

Titik sampel yang masuk dalam golongan rendah sebanyak 6 titik yaitu T1, T3, T5, T12, T13, T14. Sampel yang tergolong sedang adalah sebanyak 7 titik yaitu sampel T2, T4, T7, T9, T10, T11, T15 dan tergolong sedang. Sampel golongan tinggi terdapat pada T6, T8 dan T16.

\section{Reaksi Tanah (pH)}

Berdasarkan hasil analisa $\mathrm{pH}$ di lapangan (Tabel 1), pH tanah pada lahan perkebunan penelitian adalah masam. Nilai $\mathrm{pH}$ didominasi 5.0 dan beberapa titik bernilai 5.5. Terdapat 13 hektare yang memiliki $\mathrm{pH}$ 5,0 dan hektare yang memiliki $\mathrm{pH}$ 5.5.

\section{Rekomendasi Pemupukan}

Kelapa sawit ditanam dengan pola tanam pancang $5(8,10 \times 8,25) \mathrm{m}$ dengan penyusuaian berdasarkan kondisi laha. Sehingga, 136 kelapa sawit di tanam pada tiap hektar. Rekomendasi pemupukan untuk sampel tergolong rendah (Tabel 3) terdapat enam Titik sampel dengan pemupukan ratarata $346.22 \mathrm{~kg} \mathrm{ha}{ }^{-1}$. Sehingga, SP-36 diberikan sebanyak $2.55 \mathrm{~kg}$ pokok $^{-1}$. Ratarata dosis pemupukan sampel golongan sedang (Tabel 4) adalah $139.33 \mathrm{~kg} \mathrm{ha}^{-1}$. Pupuk per pokok diberikan sebanyak 1.02 $\mathrm{kg}_{\text {pokok }}{ }^{-1}$.

Tabel 1. Hasil analisa tanah dan kriteria $\mathrm{pH}$

\begin{tabular}{ccl}
\hline \multirow{2}{*}{ Titik Sampel } & & $\mathrm{pH}$ \\
\cline { 2 - 3 } & Nilai & Kriteria \\
\hline T1 & 5,0 & Masam \\
T2 & 5,0 & Masam \\
T3 & 5,0 & Masam \\
T4 & 5,5 & Masam \\
T5 & 5,5 & Masam \\
T6 & 5,0 & Masam \\
T7 & 5,5 & Masam \\
T8 & 5,0 & Masam \\
T9 & 5,0 & Masam \\
T10 & 5,0 & Masam \\
T11 & 5,0 & Masam \\
T12 & 5,0 & Masam \\
T13 & 5,0 & Masam \\
T14 & 5,0 & Masam \\
T15 & 5,0 & Masam \\
T16 & 5,0 & Masam \\
\hline
\end{tabular}


Tabel 2. Hasil analisa p-tersedia dan kriteria $\mathrm{P}_{2} \mathrm{O}_{5}$

\begin{tabular}{ccc}
\hline \multirow{2}{*}{ Titik Sampel } & \multicolumn{2}{c}{ Fosfor $\left(\mathrm{P}_{2} \mathrm{O}_{5}\right)$} \\
\cline { 2 - 3 } & P Tersedia $(\mathrm{ppm})$ & Kriteria* \\
\hline T1 & 4.81 & Rendah \\
T2 & 11.17 & Sedang \\
T3 & 6.06 & Rendah \\
T4 & 9.51 & Sedang \\
T5 & 6.90 & Rendah \\
T6 & 21.36 & Tinggi \\
T7 & 12.90 & Sedang \\
T8 & 20.55 & Tinggi \\
T9 & 13.98 & Sedang \\
T10 & 18.51 & Sedang \\
T11 & 10.25 & Sedang \\
T12 & 6.48 & Rendah \\
T13 & 5.56 & Rendah \\
T14 & 5.77 & Rendah \\
T15 & 10.29 & Sedang \\
T16 & 21.14 & Tinggi \\
\hline
\end{tabular}

Tabel 3. Rata-rata rekomendasi pemupukan status hara rendah

\begin{tabular}{|c|c|c|}
\hline Titik Sampel & $\begin{array}{l}\text { P-Tersedia } \\
(\mathrm{ppm})\end{array}$ & $\begin{array}{c}\mathrm{Sp}-36 \\
\text { ( kg/ha) }\end{array}$ \\
\hline $\mathrm{T} 1$ & 4,81 & 388,97 \\
\hline T 3 & 6,06 & 341,26 \\
\hline T 5 & 6,90 & 309,19 \\
\hline T 12 & 6,48 & 325,23 \\
\hline T 13 & 5,56 & 360,34 \\
\hline T 14 & 5,77 & 352,33 \\
\hline \multicolumn{2}{|c|}{ Rata-rata } & 346,22 \\
\hline
\end{tabular}

Tabel 4. Rata-rata rekomendasi pemupukan status hara sedang

\begin{tabular}{ccc}
\hline Titik Sampel & $\begin{array}{c}\text { P-Tersedia } \\
(\mathrm{ppm})\end{array}$ & $\begin{array}{c}\text { Sp-36 } \\
(\mathrm{kg} / \mathrm{ha})\end{array}$ \\
\hline T 2 & 11,17 & 146,20 \\
T 4 & 9,51 & 209,56 \\
T 7 & 12,90 & 80,16 \\
T 9 & 13,98 & 38,94 \\
T 11 & 10,25 & 181,32 \\
T 15 & 10,29 & 179,79 \\
\hline & & 139,33 \\
\hline
\end{tabular}

\section{Peta status unsur hara}

Peta dibuat berdasarkan hasil analisis di laboratorium pada Tabel 2 dan peta dasar lokasi penelitian dalam Gambar 3. Hasil pembuatan peta status unsur hara (Gambar 4). Perbedaan status unsur hara ditunjukkan melalui perbedaan warna sesuai dengan kaidah pemetaan. Warna merah mewakili status unsur hara rendah. Warna kuning mewakili status unsur hara sedang. Warna hijau mewakili status unsur hara tinggi. 


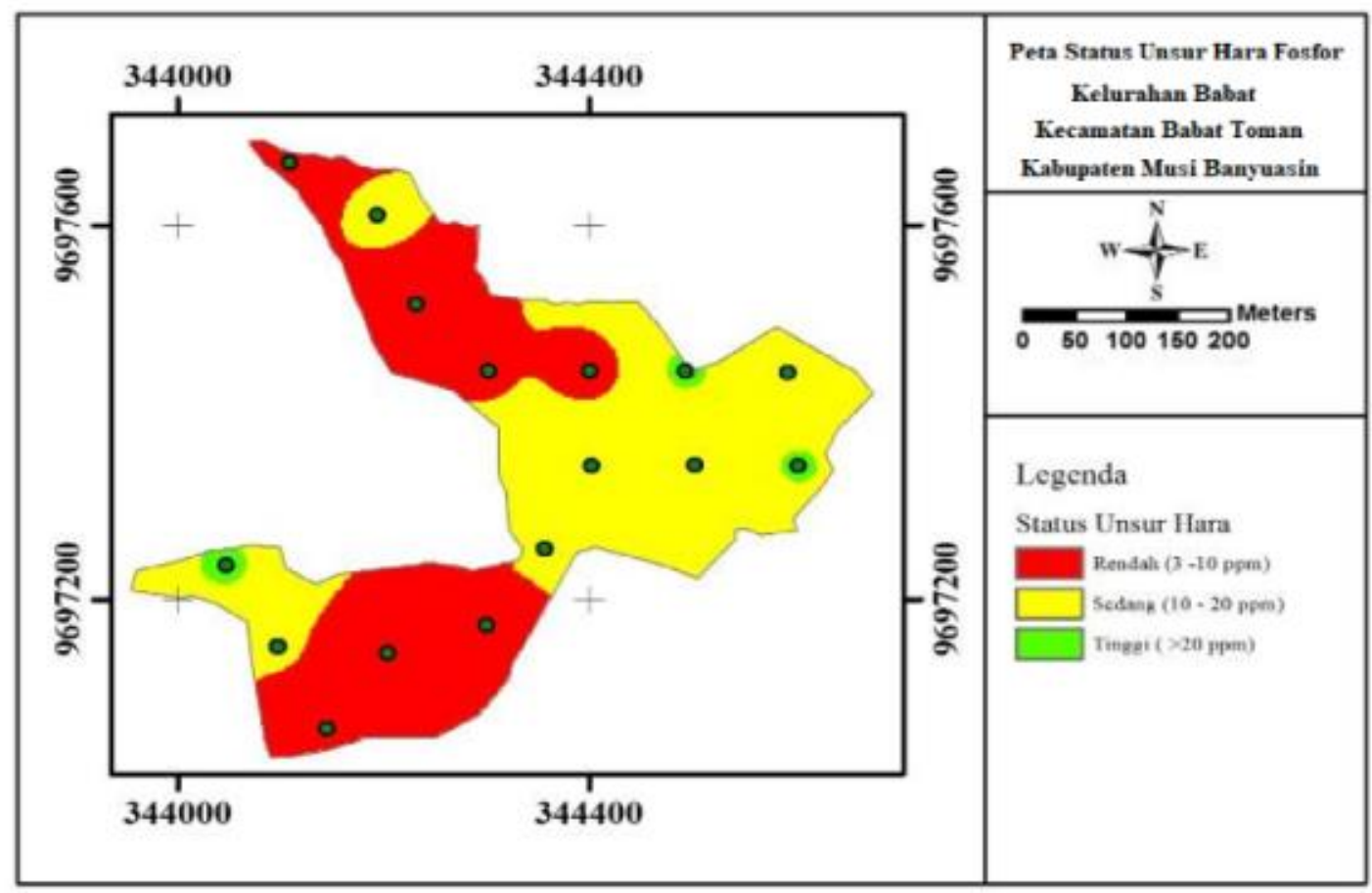

Gambar 4. Peta status unsur hara lokasi penelitian.

\section{Unsur hara Fosfor $\left(\mathrm{P}_{\mathbf{2}} \mathrm{O}_{5}\right)$}

Bagi perkebunan kelapa sawit, $\mathrm{P}$ tersedia yang tergolong dalam sedang sudah sangat baik bagi pertumbuhan kelapa sawit. Berdasarkan tabel kesesuaian kelapa sawit CSR/FAO (1983) p-tersedia yang tergolong sedang sudah masuk dalam klasifikasi S1. Namun beberapa titik dengan $\mathrm{P}$ tersedia yang tergolong rendah mampu menyebabkan pertumbuhan kelapa sawit yang tidak optimal sehingga menurunkan hasil produksi kelapa sawit. Sehingga diperlukan pemupukan yang dapat menaikkan kadar unsur hara fosfor di tanah menggunakan pupuk SP-36.

Status unsur hara di lokasi penelitian didominasi oleh golongan sedang. 7 titik sampel tergolong rendah dan 6 sampel tergolong rendah. 3 titik sampel lainnya.

\section{Rekomendasi Pemupukan}

Analisa $\mathrm{P}$ tersedia dalam tanah dapat dijadikan dasar perhitungan dosis pemupukan sehingga menjadi elebih fisien. Rekomendasi pemupukan ini bertujuan untuk menaikkan kandungan p-tersedia tanah yang tergolong dalam kelas rendah menjadi sedang dengan kadar 15 ppm. Pemberian pupuk SP-36 hingga p-tersedia mencapai 15 ppm dianggap cukup efisien untuk perkebunan kelapa sawit di lokasi penelitian.

Berdasarkan Tabel 2. diketahui bahwa 7 titik sampel tergolong sedang, 6 sampel tergolong dan 3 tergolong rendah. Perhitungan dosis hanya dilakukan pada titik sampel rendah dan sedang dengan kadar < 15 ppm. Sehingga T6, T8, T10 dan T16 dengan kadar 21.36 ppm; 20.55 ppm; $18.51 \mathrm{ppm}$; dan $21.14 \mathrm{ppm}$ rekomendasi pemupukan tidak dibutuhkan.

Golongan unsur hara rendah memerlukan peningkatan kadar dari 8.10 ppm sampai 10.19 ppm. Pemupukan menggunakan SP-36 untuk titik sampel tersebut membutuhkan dosis antara 309.19 $\mathrm{kg} \mathrm{ha}^{-1}$ sampai $388.97 \mathrm{~kg} \mathrm{ha}^{-1}$ dengan ratarata $346.22 \mathrm{~kg} \mathrm{ha}^{-1}$. Jumlah pupuk per pokok didapatkan berdasarkan dosis per luas dibagi populasi di lokasi. Populasi kelapa sawit di lokasi adalah sebanyak 136 
pokok sehingga didapat dosis $2,55 \mathrm{~kg}$ untuk tiap pokok kelapa sawit. Rekomendasi pemupukan untuk golongan rendah diberikan berdasarkan jumlah rata-rata dosis pupuk per ha untuk memudahkan pemberian pupuk di lokasi.

Sampel dengan golongan unsur hara sedang membutuhkan pupuk Sp-36 sebanyak $38.94 \mathrm{~kg} \mathrm{ha}^{-1}$ sampai $209.56 \mathrm{~kg}$ $\mathrm{ha}^{-1}$ dengan rata-rata $139,33 \mathrm{~kg} \mathrm{ha}^{-1}$. Pupuk tersebut diberikan untuk meningkatkan kadar hara titik sampel yang berkisar antara 1.02 ppm sampai 5.49 ppm. Berdasarkan jumlah populasi kelapa sawit, maka sebanyak $1,02 \mathrm{~kg}$ pokok $^{-1}$ diberikan ke tanaman.

\section{Reaksi Tanah (pH)}

Kemasaman tanah disebabkan oleh beberapa faktor seperti jenis tanah, curah hujan dan kegiatan pemupukan oleh petani. Perkebunan kelapa sawit rakyat di Kelurahan Babat ini memiliki tanah yang mirip inceptisol dan sesuai dengan peta satuan lahan dan tanah lembar Palembang, Sumatera. Tanah di lokasi peneltian memiliki $\mathrm{pH}$ yang ditunjukkan pada Tabel 1. Penggunaan lahan perkebunan dan kehutanan tidak mampu memperbaiki $\mathrm{pH}$ tanah seperti yang dinyatakan dalam penelitian Yamani (2010) dan Mindawati (2006). Penelitian Mindawati (2006) menjelaskan bahwa penanaman pohon pada lahan konversi hutan yang sudah berumur 6 tahun tidak merubah kondisi $\mathrm{pH}$ tanah. Kemudian Rahmah (2014) menemukan bahwa konversi hutan menjadi lahan Agroforestri dan perkebunan kopi tidak mampu mengubah $\mathrm{pH}$ tanah menjadi lebih baik walaupun telah dibudidayakan selama 10 dan 15 tahun.

Lahan pertanian yang selalu dipupuk tanpa pengapuran oleh petani dapat menurunkan nilai $\mathrm{pH}$ tanah. Pemupukan menggunakan urea dan NPK di lokasi penelitian dilakukan dua kali dalam satu tahun, sedangkan pengapuran dolomit hanya pada tanaman yang menunjukkan kelainan. Pemupukan dolomit secara individu tidak mampu menaikkan nilai $\mathrm{pH}$ keseluruhan pada tiap titik pengambilan sampel sehingga $\mathrm{pH}$ tanah tetap menjadi masam.

\section{Peta status unsur hara}

Peta status unsur hara dibuat untuk memudahkan penyampaian informasi mengenai status unsur hara di lokasi penelitan. Peta menyampaikan informasi status unsur hara melalui perbedaan warna dan pemisahan wilayah berdasarkan status unsur hara. Dengan mengacu pada peta, maka pemupukan SP-36 dapat menjadi lebih mudah. Pengelola kebun dapat merencanakan rute dan luasan wilayah yang membutuhkan dosis tertentu sehingga bisa sama atau mendekati rekomendasi pemupukan yang diberikan. Sehingga, pemupukan yang dilakukan lebih efisien dalam hal tenaga dan jumlah yang dibutuhkan serta input yang diberikan ke tanah.

\section{KESIMPULAN}

Sebaran $\mathrm{P}$ pada lokasi penelitian adalah dipengaruhi oleh $\mathrm{pH}$ lahan yang tergolong masam sehinnga membatasi Ptersedia di lokasi penelitian. Terlihat Ptersedia di lokasi dominan sedang (7 ha) dan rendah (6 ha) sedangkan golongan tinggi (3 ha) hanya sedikit. Rekomendasi pemupukan menggunakan SP-36 diberikan untuk menaikkan kandungan $\mathrm{P}$ tersedia agar menjadi sedang $15 \mathrm{ppm}$ dengan rata-rata dosis sebanyak 346,22 $\mathrm{kg} / \mathrm{ha}$ untuk PTersedia golongan rendah dan $139,33 \mathrm{~kg} / \mathrm{ha}$ untuk P-Tersedia golongan sedang. Pembuatan peta status unsur hara dapat mempermudah pemupukan di lokasi penelitian.

\section{UCAPAN TERIMAKASIH}

Penulis mengucapkan terimkasih kepada Progran Studi Ilmu Tanah dan Agroekoteknologi Universitas Sriwijaya beserta semua pihak yang membantu dalam pelaksanaan penelitian ini sehingga bisa selesai. 


\section{DAFTAR PUSTAKA}

CSR/FAO Staffs. 1983. Reconnaissance Land Resource Survey 1:250.000 Scale. Atlas Format Procedures. AGOF/INS/78/006. 4(1).

Faizin N, et al. 2015. Respon pemberian beberapa dosis pupuk Fosfor terhadap pertumbuhan semai akasia dan ketersediaan fosfor di tanah. JOM Faperta. 2(2): Oktober 2015, 2(2).

Föhse DCN, Jungk A. 2015. Phosphorus Efficiency of plants. I. External and Internal Requirement and P Uptake Efficiency of Different Plant Species. Plant Soil, 110, pp. 101109.

Frossard E, Condron L, Oberson A, Sinaj S, Fardeau JC. 2000. Processes Governing Phosphorus Availability in Temperate Soils.Journal of Environmental Quality. Madison, WI: American Society of Agronomy, Crop Science Society of America, and Soil Science Society of America. 29:15-23.

Hanafiah A, Ali K. 2014. Dasar Dasar Ilmu Tanah. Jakarta: Raja Grafindo Persada.

Hinsinger $\mathrm{P}$, Betencourt $\mathrm{E}$, Bernard L, Brauman A, Plassard C, Shen J, Tang X, Zhang F. 2011. P for Two, Sharing a Scarce Resource: Soil Phosphorus Acquisition in the Rhizosphere of Intercropped Species.
Plant Physiology. 156(3):10781086.

Lambers H, Plaxton WC. 2015. Phosphorus: Back to the Roots.Annual Plant Reviews Volume 48. (Wiley Online Books). doi:10.1002/9781118958841.ch1.

Mindawati N, Kosasih AS, Heryati Y. 2006. Pengaruh Penanaman Beberapa Jenis Pohon Hutan terhadap Kondisi Kesuburan Tanah Andosol', Jurnal Penelitian Hutan Tanaman. 3(1):155-164. doi: 10.20886/jpht.2006.3.3.155-164.

Rahmah S, Yusran, Harun U. 2014. Sifat kimia tanah pada berbagai tipe penggunaan lahan di Desa Bobo Kecamatan Palolo Kabupaten Sigi, Warta Rimba. 2(1):88-95.

Rosmarkam A, Yuwono NW. 2002. Ilmu Kesuburan Tanah. Yogyakarta: Kanisius.

Umaternate GR, Abidjulu J, Wuntu AD. 2014. Uji Metode Olsen dan Bray dalam Menganalisis Kandungan Fosfat Tersedia pada Tanah Sawah di Desa Konarom Barat Kecamatan Dumoga Utara. Jurnal Mipa Unsrat. 3(1): 6-10.

Yamani A. 2010. Kajian Tingkat Kesuburan Tanah Pada Hutan Lindung Gunung Sebatung Di Kabupaten Kotabaru Kalimantan Selatan. Jurnal Hutan Tropis. 11(29):32-37. 